\title{
Movement of Special Colleges for Advanced Studies and its Current Challenges in Hungary ${ }^{1}$
}

\author{
Imre GARAI, Zoltán András SZABÓ and András NÉMETH
}

\author{
ARTICLE INFO \\ Article history: \\ Received 2 April 2020 \\ Accepted 3 June 2020 \\ Available online 31 July \\ 2020 \\ Keywords: \\ special colleges for \\ advanced studies, support \\ of talented students, \\ higher education in \\ Europe and Hungary, \\ boarding schools, teacher \\ training, legal regulation, \\ ranking

\footnotetext{
I. Garai, Z. A. Szabó

Eötvös Loránd University

Faculty of Education and

Psychology •

Kazinczy utca 23-27

H-1075 Budapest •

Hungary •

garai.imre@ppk.elte.hu

szabo.zoltan.andras@ppk.

elte.hu
}
A. Németh
J. Selye University
Faculty of Education •
Bratislavská cesta 3322
SK-94501 Komárno •
Slovak Republic •
andras.nemeth@ujs.sk

\begin{abstract}
Movement of Special Colleges for Advanced Studies and its Current Challenges in Hungary

The history of special colleges' movement traces back to the last decade of the $19^{\text {th }}$ century in Hungary. Furthermore, its European origin can be found in colleges of medieval universities. Although this collective support of talented students has British and French origins as well, the institutionalisation of this movement can be seen as special Central-Eastern European and Hungarian development. The Baron Eötvös József Collegium founded in 1895 was the first representative institution of this movement. From the middle of the $20^{\text {th }}$ century, several other institutions were established that followed different patterns in supporting university students during their studies. However, the expansion of this movement occurred after the political transformation of 1989-1990 in Central-Eastern Europe. That was a parallel process with capacity growth of higher education, which was forced by changing social perception of higher education and transformation of the higher education policy.
\end{abstract}

\section{Introduction and problem statement}

After a few-year-long and less intensive period, "gifted education" attracted a bigger attention in the last decade's international educational literature (Wolfensberger, 2015, pp. 5-6.). This period also led to the emergence of new higher education-related publications in the field of talent development. However, one of their collective forms, the so-called "special college"

\footnotetext{
${ }^{1}$ Supported by the ÚNKP-17-4 New National Excellence Program of the Ministry of Human Capacities.
} 
remained a less frequent research aspect in the international scientific discourse. This is mainly due to the special colleges' geographical scope; these institutions are organised in the higher education systems of East Central Europe, or - more precisely - Hungary and its neighbouring countries (cf. Farkas, 2009; Feledy et al., 2014). ${ }^{2}$ Nonetheless, there is a broad consensus that the network of these institutions occupies an important place in the talent development and elite training of Hungarian education. Recently published research reports (Fazekas and Sik, 2007, 2008; ADITUS, 2011) and some other publications (Demeter, 2012; Feledy et al., 2014; Sik, 2007) suggest that there is growing attention to the history of special colleges movement in Hungary. ${ }^{3}$ Even one of the Hungarian education journals, the Educatio, dedicated a whole issue to this topic. Continuing this trend, in this paper, we intend to share some results of our research about special colleges dedicated to support talented students during their university career. ${ }^{4}$

The main research questions of our article are the following:

- what is the origin story of the special colleges?

- what are the key functions and distinctive peculiarities of the special colleges' training?

- how did these features change since the establishment of the first college?

- which characteristics can be regarded as stable?

- how did special colleges influence the development of higher education institutions?

Accordingly, in the first half of our paper, we examine the origin and development process of special colleges as a type of higher education institution. We argue in favour of relating this type of institute to the formation of medieval universities. In this period, those institutional types were established, determining the development of European university models in the $16^{\text {th }}$ and $17^{\text {th }}$ centuries. Additionally, we also want to point out the changes of ideas and transformation of European societies and the impact of these questions on the development of universities during the area of Protestant and Catholic Reformation and later in the modern ages. Hopefully, these developments will illuminate the peculiarities of Hungarian higher education, in which the first special college was established in the last quarter of the $19^{\text {th }}$ century.

We follow the development process and segmentation of special colleges' movement until the political transformation of 1989-1990. As for the segmentation, we also look through the political and professional debate, which were entwined with this historical process. At this

\footnotetext{
${ }^{2}$ For the history and the contextual perspective of the Hungarian public and higher education, see the writings of Nagy (2006) and Szögi (2008). Additional (period-specific) literature is listed at the relevant footnotes.

${ }^{3}$ The Hungarian term 'szakkollégium' can be translated into English in number of ways (e. g. 'special college for advanced studies', 'college for advanced studies', or 'special college'). In most cases, we used its shortest form ('special college').

4 This paper is based on our presentation at the Hungarian National Education Conference in 2016 and its published version in the conference's volume (Garai and Szabó, 2017).
} 
point, in the second half of our essay, we give some additional information about the current situation of special college movement and legislation changes between 1990-2016.

\section{Emergence of special colleges as unique type of institutions}

As the result of the organisation of medieval universities and peculiarities of medieval university studies, a new type of institutes became prevalent with the aim of supporting and systematising scientific work. At the University of Oxford colleges were set up in order to provide tuition and accommodation for students with foreign background in the end of the $12^{\text {th }}$ century and early $13^{\text {th }}$ century. Nevertheless, tuition became a more significant activity at these institutes (Mikonya, 2014, p. 149). College membership was profitable for students at least in two aspects. Firstly, colleges were founded by wealthy members of the elite and maintained by endowments, which could provide scholarships for talented students with lower social background. These scholarships often covered the whole or at least one part of university fees. Secondly, colleges guaranteed not just financial and existential aid (accommodation, meal), but also exceptional scientific infrastructure, including a library and scholar-teachers (tutors). Thus, core elements of university studies began to relocate to colleges in the $14^{\text {th }}$ century as the consequence of providing students with systematic scientific work and financial stability. As the result of close cultural relations between Britain and France, colleges became more and more important institutions at the University of Paris. Their inner structures, including their regulation and staff of teachers, developed in a long term (Mikonya, 2014, p. 175). Moreover, colleges offered far more services than convicts and halls, which provided students with accommodation and meals and, in some cases, scholarships. Their institutional profile was shaped by the scientific work, for which they specialised.

Protestant and Catholic Reformation exerted key changes on the development of education by expressing the need for public education and mother-tongue instruction in schools in the continental Europe. Using of humanism's erudition, in which ancient authors and their artefacts played an important role, both Protestants and Catholics were in favour of fostering foundation of Latin schools (protestant colleges, Jesuit gymnasiums, academies) (Müller, 1987 , p. 25). These basic school types' main objectives were to create commitment towards classical knowledge by establishing and using basic principles of college education and train pastors and educated citizens (Ringer, 1987, p. 70). Thanks to college education, studies became more systematic and their graduates were more efficient at ars faculties of universities. In the $16^{\text {th }}$ century, colleges existed in Paris, which preconditioned their students for advanced studies at the university (Mikonya, 2014, p. 311). In 1548, the first founded Jesuit College in Massine became a certain prototype of college education, which was based on strict order and new pedagogical principles. These principles aimed at taking an interest in classical knowledge and commitment towards reformed Catholic beliefs (Pukánszky, 2004, p. 422; Mikonya, 2014, p. 360).

Likewise, as the importance of preparation colleges for university studies became more apparent, university colleges played an even more significant role within universities. Institutionalisation of the structure of the colleges had reached a certain level until the $16^{\text {th }}$ 
century, to the point that they elected their own leaders and became more autonomous against university faculties. Even university studies were connected to these institutions in a further growing extent. In spite of the fact that colleges were less able to provide their autonomous status within the structure of universities thanks to the influence of Catholic Church in France, it also occurred that the majority of university studies were delegated to university colleges. Thus, the core part of university training belonged to these institutions (Mikonya, 2014, pp. 355-360).

On the one hand, industrial revolution and enlightenment, as well as their social consequences, contributed to slow institutionalisation and diversification of different scientific fields. On the other hand, the dissolution of the Jesuit order encouraged enlightened absolutist monarchs in Central-Eastern Europe to phase in new university reforms in the $18^{\text {th }}$ century. Thus, special colleges were founded, which were dedicated for a certain scientific area or a certain period of university studies (like repetitive colleges for teacher candidates) (Németh, 2005a, pp. 105-108).

At the dawn of modern ages, political and social revolutions indicated the birth of national states, which made it clear at the very early period of their existence that they wanted to regulate educational affairs. By transforming educational institutions and organising them into a coherent system, they also set out new theories about educational concepts. These concepts were manifested in Prussian Bildung, French culture générale and English gentleman education notions. The elite and upper middle class tried to slow down the social mobility generated by the foundation of the public education systems and they transformed their social and economic capital into academic positions. By achieving these positions, they could regulate the operation of the school system and thus, they could also control social mobility (Ringer, 1987, pp. 70-71). To achieve this aim, they established a new type of secondary schools and they transformed inherited school types from the area of the $16^{\text {th }}$ century. They provided unique status for these schools with concentrating those skills and knowledge that were essential for university entrance. Furthermore, applying for university admission was possible for those students who graduated these privileged transformed schools (Müller, 1987, p. 22). By using pedagogical principles of Jesuits, new type of boarding secondary and university colleges emerged in Britain and in France too. The entire staff of teachers and often entrusted elder individuals of the members exercised total control over the students. Therefore, they could authorize the education and socialization of new type of citizens according to regulations of the upper classes (Honey, 1987, p. 155; Ringer, 1987, p. 71).

Indeed, transformation of secondary schools did not prevent higher education institutions from implementing changes. It could be observed for the request of systematising the studies. In the aspect of Hungarian special college movement, we have to point out the French higher education reforms between 1793-1808, in which the time period colléges and lyceums as core elements of the new French public educational systems were established (Németh, 2005b, p. 15; Garai, 2011, p. 183). Lyceums were set up in municipal areas and cities. This type of secondary school focused on ancient authors in its curriculum. Nevertheless, colléges 
existed in rural areas and its curriculum put practical knowledge in its focus. More prestigious schools were those special training institutes, which were upgraded to university faculties and trained highly qualified and loyal experts for the need of the state. A few of them exceeded the awaited standards and provided students with additional scientific training. Applying for admission to grandés écoles was possible only by graduating in certain Parisian preparation secondary schools, which made their graduates fit to learn the requested knowledge to comply with the regulations of the entrance exam. Grandés écoles prepared their students for final competitive examination (aggregation) and thus it guaranteed social mobility into the elite (academic positions, high-ranking ministerial clerks or even representative political functions) (Karády, 2005, p. 185).

\section{Formation of Hungarian special college system for advanced studies}

The emergence of Hungarian special college movement could be related to formation and institutionalisation of secondary teacher profession. Educational politicians came up with the idea of setting up a new institute in the late 1870s, which they wanted to export from the French university system. The unsystematic scientific work of the philosophy faculty in the capital even made it strengthen the argument of the supporters of this plan. Baron Eötvös József Collegium's foundation was inspired by the Parisian École Normale Supérieure. Although the new teacher training boarding school undoubtedly followed a French pattern curriculum, it was not just a single copy of the home institution (cf. Karády, 2005, p. 183). Moreover, the foundation of Eötvös Collegium resulted in transforming and creating a new type of teacher training system at the University of Budapest, which inspired reforms in the Parisian institute (Garai, 2016, p. 50; Pukánszky, 2012-2013, pp. 80-81). In 1904, French public education minister's special representative observed the inner life and training system of the Eötvös Collegium to collect information for the upcoming reforms of the École Normale. $^{5}$

The Eötvös Collegium combined the advantages of boarding schools' system with teaching in small group seminars. Founding fathers of the institute and educational politicians hoped that this unique combination would result in raising the standard of teacher training. The direct authority of the students was exercised by the director and members of the teaching staff of the institute. Additionally, their authority was supported by the unique inner system of the institute, called 'family system'. Members of the family ('father' graduating member of the institute, 'mother' $3^{\text {rd }}$ year student, 'freshman' $2^{\text {nd }}$ year student and 'novice' $1^{\text {st }}$ year student) were also entrusted with guarding over moral and ethical issues, as well as supervising scientific work of each other. ${ }^{6}$ By using this type of education, the institute attempted to create a new archetype of secondary school teacher. On the one hand, members of the boarding school were expected to show an outstanding performance during courses

\footnotetext{
${ }^{5}$ Géza Bartoniek's letter for the Minister of Religion and Public Education about the planned trip to visit the École Normale Supérieure. 37/1909. Budapest, $6^{\text {th }}$ May, 1909. 38 ${ }^{\text {th }}$ box, $63^{\text {rd }}$ dossier. Mednyánszki Dénes Library and Archives (MDAL), Budapest.

${ }^{6}$ See about this question the Regulation of the Baron Eötvös József Collegium. Inner order of seminars and the library (1895). 50 $0^{\text {th }}$ box, $95^{\text {th }} / \mathrm{a}$ dossier. MDAL, Budapest.
} 
of the university and the inner seminars of the Collegium. On the other hand, they had to internalise the etiquette of Hungarian upper classes. Students were also expected to learn French language for which the institute provided French lectors. ${ }^{7}$ Therefore, we can say that the Collegium prepared their graduates for being a member of the upper middle class, in which secondary teachers belonged in the era of the Dualist Monarchy. ${ }^{8}$

Many graduates of the first generation of the institute became full professors of the University of Budapest in the early 1920s. ${ }^{9}$ Consequently, training aim and training system of the institute also changed, resulting in reshaping of the perception of the institute in public opinion. From this period, it was considered as an elite training institute, which affected the self-image of the Collegium, too. The institute's results in training scholars and teachers encouraged educational politicians to spread the model of Eötvös Collegium and to establish similar boarding schools near other universities in the country. The Act of Parliament in 1924 (About training and certification of secondary teachers) set out to extend the teacher training model that was established at the University of Budapest in 1899 (Garai, 2016, p. 50). This resulted in founding teacher boarding schools in Debrecen ${ }^{10}$ and Szeged ${ }^{11}$ that followed the pattern of the Eötvös Collegium. The latter boarding school proved to be a successful foundation. The Eötvös Loránd College ${ }^{12}$ was set up by Zoltán Bay and István Náray-Szabó in 1931. The foundation of the institute complied with the prescription of the legislation in 1924 and its aim was to train scholars for natural sciences (Garai, 2016, pp. 236-237).

Although in the early period of special college movement emerged institutions that represented the same institutional model, gaps soon became obvious. These conceptual misunderstandings soon became apparent and resulted in secession in the movement. A new type of institute emerged in this period. Eötvös Collegium in Budapest objected the fact that a teacher status was reserved for István Náray-Szabó, who was the head of the Eötvös Loránd College. As a result of this measurement, Pál Teleki, the curator of the boarding school in the capital, sent a request to the Minister of Religion and Public Education in order to achieve the dissolution of the institute in Szeged and disengagement of the occupied status. He pointed out that there was no need for Eötvös Loránd College because Eötvös Collegium trained natural scientist as well. ${ }^{13}$ His request was postponed until 1946, therefore directors and

\footnotetext{
${ }^{7}$ Loránd Eötvös curator's letter for Gyula Wlassics, Minister of Religion and Public Education for finding a French language lector in the Collegium. 21/1895. Budapest, November, $1895.46^{\text {th }}$ box, $84^{\text {th }} / \mathrm{a} / 1^{\text {st }}$ dossier. MDAL, Budapest.

${ }^{8}$ For further details, see Garai (2019, pp. 36-38).

${ }^{9}$ For the higher education policy of the Horthy era, see the paper of Fizel (2015).

${ }^{10}$ Imre Dóczi's letter for Géza Bartoniek about connections of Eötvös Collegium and teacher training institute. Debrecen, $24^{\text {th }}$ August, $1925.50^{\text {th }}$ box, $95^{\text {th }} / 2^{\text {nd }}$ dossier. MDAL, Budapest.

${ }^{11}$ Both Debrecen and Szeged are major cities in the eastern part of Hungary.

${ }^{12}$ Loránd Eötvös was an internationally known physicist and educational politician. He was also Minister of Religion and Public Education between 1894-1895. He played a significant role in setting up the teacher training school in the capital in 1895. His father was József Eötvös, the first Minister of Religion and Public Education in Hungary, whose name was given to the teacher boarding school in Budapest.

${ }^{13}$ Pál Teleki curator's letter for Bálint Hóman, the Minister of Religion and Public Education. Budapest, $30^{\text {th }}$ December, 1931. $41^{\text {st }}$ box, $73^{\text {rd }} / 4^{\text {th }}$ dossier. MDAL, Budapest.
} 
curators kept this question on the agenda in their discourse with ministerial officials and urged them to solve this problem (Garai, 2016, pp. 223-224).

In the second half of the 1930s, a considerable part of the Hungarian political and intellectual elite thought that leading positions and social strata needed to be refreshed and occupied by individuals from the agricultural and working classes. According to Lajos Zilahy's views in the 'debate of school for excellences', we can identify a major fracture point in the movement of special colleges, whose consequences still have effect on the current agenda of the movement. Zilahy admired the training system and selection processes of the candidates of Eötvös Collegium in his letters and in his media appearances. Nevertheless, he pointed out that, in case of founding an own institute, it would have focused on training political leaders from candidates who represented the poor. During his observations in Eötvös Collegium and conversations with Miklós Szabó, the head of the institute between 1935-1944 and interactions with students of the boarding school, his views were modified about principles of a new type of college (Szabó, 1942, pp. 9-10). In spite of the fact that he could not realise his intentions, socially sensitive groups of the political elite founded a new college in 1939. The new institute's name was Bolyai College, ${ }^{14}$ which was changed later to Györffy College. ${ }^{15}$ In the first phase of the operation of the college, Zilahy's views played a significant role (Papp, 2005, pp. 118-119).

Students of the Györffy College defined themselves as political opponents to the Horthy-regime and they were willing to demonstrate avowedly by taking part in political actions. Learning and teaching methods also helped students to reflect on current political and social problems, consequently, they were encouraged to be involved in discussions on social issues (Pataki, 2005, pp. 151-152). The archetype of politically active intellectual was amplified by disastrous consequences of the World War II in Hungary and political propaganda of democratic political parties especially, promises of Hungarian Communist Party. ${ }^{16}$ Thus, students of Győrffy College became vanguard of democratic values based state as pupils of the central college of Alliance of National Folk Colleges, which was founded in July 1946.

As central college of this organisation, Györffy College could have spread its institutional model. The institute was in a privileged position as supporters of the Communist party, consequently their expansion coincided with political aims of Communists. Students of the college became committed to aims of Block of Leftist Parties ${ }^{17}$ and they were ready to comply with the expectations of these parties both in general political or higher educational political issues. The Communists were provided with easily mobilised activists. In turn, Győrffy College gained state protection for establishing new colleges followed its institutional pattern. Interestingly, it had an important outcome because this resulted in widening the disciplinary

\footnotetext{
${ }^{14}$ The name referred to János Bolyai who was a Hungarian mathematician.

15 János Györffy was a researcher of Hungarian folklore.

${ }^{16}$ For the detailed introduction of the Hungarian educational system during the Socialism, see Braham (1970).

${ }^{17}$ Block of Leftist Parties was established on $5^{\text {th }}$ March, 1946. The Block was set up by the initiation of the Communist party and its aim was to unite those parties that wanted to overthrow Ferenc Nagy, who led central rightist government.
} 
frames of special college movement. Therefore, new colleges were established, and they focused on other disciplines instead of philosophy and natural sciences (Pataki, 2005, p. 238). Presumably, foundation of new colleges also played an important role in dynamically growing numbers of university admissions after 1945, which was an essential component of the higher education concept of the Communist party (Ladányi, 1999, p. 73).

In the time period of 1945-1949, two types of colleges existed that differed from each other strikingly. The Eötvös Collegium acknowledged the importance of democratic values and it resulted in consequences in its curriculum. Sándor Szalai led Sociology become an important and mandatory subject for members of the institute. ${ }^{18}$ Nevertheless, its main training aim did not change. As opposed to Eötvös Collegium, Alliance of National Folk Colleges trained politically active and committed intellectuals towards aims of the Communist party. As the political contest became sharp, the two institutes were depicted as lethal rivals of each other in demonstrative political events. This collision of the institutes was amplified by the 'special college debate' in the media. In the second half of the debate, politicians took part in the discussion by writing articles in which they set out their intentions about Eötvös Collegium. They left no doubt about the future of the institute and promised transformation in accordance with the 'advanced political spirit' (Garai, 2016, pp. 365-371).

As the political sphere had transformed in Hungary in the end of 1940s, Stalinist-type dictatorship was established that resulted in elimination of both institutes. Alliance of National Folk Colleges was abolished by its close relationships with politics. The whole institute, including Györffy College, was stigmatized and its patron was sentenced to death in Rajk-trial in September $1949^{19}$ (Pataki, 2005, pp. 401-402). Eötvös Collegium's operation was ceased by 'double university reform' in 1949-1950. The boarding school was replaced by Soviet pattern based on a simple student accommodation (Garai, 2016, p. 415).

After 1950, the whole system of Hungarian education changed significantly. The political regime attempted to establish Soviet-type institutions and scientific training and ranking system (Ladányi, 1999, p. 50; Garai, 2016, pp. 126-127). Scientists from these areas were judged by their effectiveness and accuracy of following political indoctrinations of the Communist party (Németh and Biró, 2016, pp. 43-45). Eight months lasting training program played a key role in creating a new generation of scientists, which was founded in November 1949 with the aim of preparing candidates for scholarships in the Soviet Union. This preparation course had been institutionalised since 1950. The institute was given the name of Oleg Kosevoj Soviet Scholarship College. This institute used boarding-school-type educating system in order to prepare students for learning at Soviet universities. Education

\footnotetext{
${ }^{18}$ Report of Sándor Szalai about his Marxist lectures in 1946/1947. Budapest, $19^{\text {th }}$ June, 1947. 54 ${ }^{\text {th }}$ box, $101^{\text {st }}$ $/ 10^{\text {th }} / \mathrm{a}$. dossier. MDAL, Budapest. Sándor Szalai was the head of Institute of Sociology at University of Budapest. He also played a political role as a prosecutor in a court case of a former prime minister László Bárdossy.

${ }^{19}$ László Rajk was the patron of the Alliance of National Folk Colleges as Minister of Internal Affairs. He was relatively popular politician in Hungary after the war. Presumably, that was one of the reasons why he was selected as the victim of this show trial by Mátyás Rákosi, the supreme leader of the Communist party, between 1948 and 1953.
} 
lasted for 11-12 months (Siklósné, 2016, pp. 88-89). In fact, students had to spend most of their time learning ideological and Russian language courses. ${ }^{20}$

In the early period of the operation of the boarding school, 400 students were enrolled in 4 disciplinary groups (engineers, teachers and physicians, economists and agronomists). According to the curriculum, students had to spend 17 hours learning and doing other educational activities. They were not allowed to do individual programmes. All of their collective exercises were authorised by members of the teaching staff (Siklósné, 2016, pp. 91-95). Consequently, the new institute trained members of new generations of scholars who gained their qualifications in Soviet universities and they could facilitate of Sovietisation of Hungarian scientific life after their return from the Soviet Union (Garai, 2016, pp. 126127).

The main aim of the institute was to train scholars who were able to follow actual political descriptions of the party during their scientific work. However, this aim was not achieved due to insufficient preparatory works of founding of the institute and conflicts between members of the teaching staff. Moreover, students were admitted with divergent previous gained knowledge and skills. These divergences were so striking that the institute only focused on the selection of students for Soviet scholarships and political education (Siklósné, 2016, pp. 108109). Admitted students were not allowed to leave the institute during the school year, hence they lived separated from the surrounding world. Some of them began to think that they were highly regarded. Having been too self-confident was one of the reasons why students' performance during their scholarship in the Soviet Union was unsatisfactory. ${ }^{21}$ Although the results of the institute had been rising during the school year of 1951/1952, ${ }^{22}$ the institute's operation was ceased in 1954 by decree of Political Committee of Hungarian Workers ${ }^{23}$

Ideas about re-establishing special colleges were prevailing in newspapers that were published during the area of the revolution in 1956 and shortly after the Soviet intervention and forming of the Kádár-regime. ${ }^{24}$ As the retaliation began in April, 1957 and political power of the party became stable, negotiations started about restructuring the system of higher education and restoration of special colleges (Ladányi, 1999, pp. 95-96). New education conception of the new regime formed slowly from the middle of 1957 (Kalmár, 1998, pp. 138-141). At least, Gábor Tóth as director of student accommodation number $20^{\text {th }}$ was given permission

${ }^{20}$ [Sine nomine]: Proposal for the Secretariat of the Hungarian Workers Party about preparing of winners of Soviet scholarships in 1952. Budapest, $24^{\text {th }}$ April 1951. Session of Secretariat of Hungarian Workers Party in $25^{\text {th }}$ April, 1951. 276 ${ }^{\text {th }}$ fond, $54^{\text {th }}$ bunch, $140^{\text {th }}$ unit. Hungarian National Archive (HNA), Budapest.

${ }^{21}$ Report about performance of students at universities and technical schools in the Soviet Union in the school year of 1951/1952. Budapest, $4^{\text {th }}$ February, 1953. XI.429/III.21. Secretary of Hungarian Workers Party's session in $4^{\text {th }}$ February, 1953. $276^{\text {th }}$ fond, $54^{\text {th }}$ bunch, $229^{\text {th }}$ unit, pp. 46-52. HNA, Budapest.

${ }^{22}$ Márton Horváth: Proposal about students' admission of Oleg Kosevoj Soviet Scholarship College in the school year of 1952/1953. Budapest, February, 1952. Secretary of Hungarian Workers Party's session in $13^{\text {th }}$ February, $1952.276^{\text {th }}$ fond, $54^{\text {th }}$ bunch, $180^{\text {th }}$ unit, p. 42 . HNA, Budapest.

${ }^{23}$ Márton Horváth-Erzsébet Andics: Report about education results of Oleg Kosevoj Soviet Scholarship College. Budapest, 23 ${ }^{\text {rd }}$ July, 1953. 744/53. Political Committee of Hungarian Workers Party's session in $29^{\text {th }}$ July, 1953. $276^{\text {th }}$ fond, $53^{\text {rd }}$ bunch, $128^{\text {th }}$ unit, pp. 43-47. HNA, Budapest.

${ }^{24}$ After the Soviet intervention in 1956, János Kádár became the supreme leader of the new state party, the Hungarian Socialist and Workers Party. 
to introduce special seminars for those chosen students who were interested in additional studies (Ladányi, 2008, p. 110). After a while, these advanced studies became decisive in the accommodation, which existed in the headquarters of the former Eötvös Collegium. Students supported the idea of restoring the boarding school and they declared that the institution would use the name of József Eötvös again. The Eötvös Kollégium put its focus on training scholars as its predecessor (Fazekas and Sik, 2007, pp. 77-81). Students were expected to complete at least one extra seminar for their subject and they also had to learn history of philosophy and modern language courses. Parallelly, Eötvös Loránd College was also re-established in Szeged in 1957. Restoring of former elite teacher training institute implied that new political regime wanted to raise the standard of teacher training (Ladányi, 2008, p. 110). By implementing reforms at universities and even in the Hungarian Scientific Academy in the late 1960s and early period of 1970s, made it possible to set up Rajk László College in March 1970. These reforms pointed out the importance of sciences in achieving and maintaining the socialist political and social order (Szabó, 2016, pp. 218-223). Furthermore, transformed political perception of the academic sphere allowed higher education institutes to use 'democratic' principles during their operation. Scientists and scientific institutions were only expected to follow curricular descriptions and the current political agenda (Ladányi, 2008, pp. 123-125). Presumably, that was one of the reasons why it was granted foundation of Rajk College. The new institution considered that scientific and social issues of students are equally important in its curriculum. That perception of education tasks complied with the expectations of education policy and made it slightly different from Eötvös Kollégium. It became similar to Győrffy College type special colleges. Rajk College was also unique because the formation of its institutional frames lasted long and it tried to hand over its experience to new colleges. They provided regular information for Social Theory College (1981) and Bibó István College (1983), which played a key role in political transformation in 1989 (Fazekas and Sik, 2007, p. 101). In these institutions, key element of college education was to create commitment towards democratic values and self-government by gaining experience about these phenomena. Students of these colleges felt impelled to play an active role in political changes in the late 1980s in the early period of 1990s.

As we pointed out above, Hungarian special college movement was comprised two different types of institutions. One of them put its focus on scientific training and providing the country with scientific supplement. Nevertheless, the other type of special colleges deemed that scientific training and active citizenship attitude were equally important. The latter was experienced by self-governing in the newly established colleges in the 1980s.

By the mid-eighties, the place of these institutions' encounter was the Summer Meeting of Special Colleges (Nyári Szakkollégiumi Találkozó-abbreviate name: NYATA) (Forray, 2016, p. 315). ${ }^{25}$ The idea of the conference was born in 1984 , and related to the members of the Rajk College, who started to organise the first meeting (1985, Szarvas) with the Bibo College (later, the Martos College and the Münnich College of the Technical University of Budapest, and the Tóthfalusi College in Debrecen also joined) (Pünkösti, 2013). In order

\footnotetext{
${ }^{25}$ A smaller circle of special colleges had organised meetings since 1981 (Pünkösti, 2013).
} 
to reduce the political pressure, they promoted the event under the name 'IV. National Meeting of Special Colleges’ (IV. Országos Szakkollégiumi Találkozó) (Pünkösti, 2013). The first three NYATA (in Szarvas, Pápa and Balatonszárszó) were characterised by this strong political orientation, but after 1988, mostly the strengthening and defining of the special college movement were on the agenda of the meetings (besides this, each one had a key topic). ${ }^{26}$

This intention to self-determination became more reasonable because of the political change in 1990. Due to the new social demands of market economy, the legal status of the special colleges, the character and the number of their training went through significant changes, as they expected the colleges to educate a new type of professionals. ${ }^{27}$

\section{Special colleges after the political change}

Accordingly, the new challenge for the special college movement was to place itself in a brand-new field of force, determined by the changed economic and social conditions. One of the first steps was the achievement of wider legal certainty. However, it became a particularly difficult process because the legal environment itself has profoundly changed. This renewal affected the highest level of non-sector-specific laws, but also the regulations of higher education and other documents of a legal nature. The regulations covering the special colleges can be divided into three big groups, as shown in detail below.

As we have highlighted previously (cf. Garai and Szabó, 2015, p. 122), the narrower legal environment is constituted by the (higher) education acts ( $1^{\text {st }}$ Act of the Parliament in 1985, $80^{\text {th }}$ Act of the Parliament in 1993, $139^{\text {th }}$ Act of the Parliament in 2005), their modifications and the related decrees.

In a broader sense, considering accreditation, other legal sources can be taken into account, which are listed by the Educational Authority (Oktatásügyi Hivatal-abbreviate name: $\mathrm{OH}$ ). ${ }^{28}$ Among the items of the list, legal sources of higher education, public administration and the Educational Authority itself can be found as well. However, none of these describes the exact criteria of special colleges' accreditation, they delegate those to non-governmental bodies and documents that do not fall into the set of the source of law.

Consequently, in the broadest sense, the documents outside the sources of law are also the part of the regulation of the accreditation of the special colleges. These include the Charter of Special Colleges (Szakkollégiumi Charta-abbreviate name: Charta), written in 1991 in Zánka, and modified in 2001 and in 2011 (cf. ADITUS, 2011, p. 22), or the documents of the Conciliatory Forum of Special Colleges (Szakkollégiumok Egyeztetö Fóruma-

\footnotetext{
${ }^{26}$ Besides its other functions, this body is responsible for the accreditation of the special colleges [online]. [cit. 2017-04-30]. Available at: http://www.szakkoli.hu/?id=24.

${ }^{27}$ As it can be seen below, the political change in Hungary had a huge impact on the movement of the special colleges. For the political and historical background of this period's education, and for the comparison with other East Central European countries' transition, see Bîrzea (1994), Karsten and Majoor (1994), Radó (2001), Čerych, Koucký and Matějů (1999).

${ }^{28}$ [online]. [cit. 2017-04-27]. Available at:

https://www.oktatas.hu/felsooktatas/hatosagi_ugyintezes/szakkollegiumok_nyilvantartasba_vetel.
} 
abbreviate name: SZEF). ${ }^{29}$ While the Charter summarises the criteria for "becoming a special college" (Márkus, 2014, p. 62), the documents of the Conciliatory Forum describe its practical-operative aspects.

The accreditation of the special colleges crosses all the three levels, but the first and the last are particularly important. According to the $204^{\text {th }}$ Act of the Parliament in 2011 (about the national higher education) "the education policy considers the special colleges (as a service) to be an integral part of university-level training." (Márkus, 2014, p. 62).

Accordingly, the Act highlights that the higher education institutions maintain talent support and alignment systems and programs, and it mentions the special colleges and the Roma special colleges, too. On the other hand, the government tasked with the detailed regulation of talent developing, including the principles of the special colleges' organisation. ${ }^{30}$

This has led to the Government Decree 24/2013 (II. 5.) about excellence in national higher education, which introduced those principles and initiatives which as intentions and prior signs, are formerly revealed by the study of ADITUS (2011). ${ }^{31}$

Besides this, the decree strengthens the decision about the public support of special colleges, sets down the aims and principles of their functioning, the access of the special colleges' services and their integration with the higher education system, and also the registration and control of the special colleges by the Educational Authority. ${ }^{32}$

Maybe the biggest innovation of the decree is the specification of the above-mentioned Conciliatory Forum (SZEF), which is defined as a body for the negotiation and representation of interests. According to the self-definition of the SZEF — its unofficial, but more frequently used name is Interkoll - it is "the forum and decision-making body of the special college movement", and aims at the promotion of the special colleges' cooperation. ${ }^{33}$ However, the functioning of the SZEF extends beyond these definitions, because it is also responsible for the accreditation of the special colleges. In order to achieve this, it elects two bodies: the so-called Ranking Committee (for 3 years), and the Committee on Ranking Facilitation (for 5 years), which relieves the former one. ${ }^{34}$ The Ranking Committee evaluate the special colleges according to four group of points, based on the principles of the Charter: a) autonomy, b) professional and scientific functioning, c) social responsibility, d) material aspects (number of members, common accommodation, e.g. dormitory). ${ }^{35}$

\footnotetext{
${ }^{29}$ See the different versions of the Charter and additional documents on the web page of the SZEF [online]. [cit. 2015-11-03]. Available at: http://www.szakkoli.hu/oldal/szakkollegiumi-charta.

$\left.{ }^{30} 110 . \S(1) .12 . b\right)$.

${ }^{31}$ ADITUS (2011); This paper analyses the decree's text according to its form on 2015.12.09.

${ }^{32}$ See the relevant legal sources on the web page of the Educational Authority [online]. [cit. 2015-10-12].

Available at: http://www.oktatas.hu/felsooktatas/hatosagi_ugyintezes/szakkollegiumok_nyilvantartasba_vetel.

${ }^{33}$ See in more details: Ranking procedure of special colleges, p. 1. (Szakkollégiumi Minösitési Eljárásrend) [online]. [cit. 2015-11-10]. Available at: http://szakkoli.hu/sites/default/files/eljarasrend_2014.11.28_1.pdf.

${ }^{35}$ See in more details: Ranking procedure of special colleges.
} 
Based on the above-mentioned criteria, the committee categorises the institutions into four groups every year: a) "accredited special college" (for 3 years), b) "accredited special college" (for 1 year), c) "promise of special college", d) rejecting the application. ${ }^{36}$

The first accreditation procedure was organised in 2011 (Márkus, 2014, p. 67), which data, with the results of the former researches, can reveal the size of the special colleges' network.

\section{The expansion of the special college movement}

As we pointed out earlier (Garai and Szabó, 2015, p. 123), due to the lack of a single source base, it is hard to examine the changes in the special college movement's size after 1990. Nevertheless, it is sure that the economic, social and legal changes had brought not only the shift of the special colleges' function and profile but also the growth of these institutions. At the beginning of the ' $90 \mathrm{~s}$, the special college movement showed a great extension, and after 2000, the pace of growth speeded up even more. As a result, their number passed 20 at the millennium, and in 2006 almost 40 special colleges functioned - cf. Fazekas and Sik (2007, p. 10).

This upsurge is closely linked to the massification of Hungarian higher education: while in 1990/1991 (school year) the colleges and universities had 108376 students, in 2000/2001 already 327289 people studied in higher education. ${ }^{37}$ The number of students (see Figure 1) reached its maximum in 2005/2006 (424 161), and after this peak, a continuous decline was recorded (in 2016/2017, 287018 was the number of students). ${ }^{38}$ In spite of this strong reduction, the number of the institutes, after their integration in 2000, shows smaller amplitude and ranged between 62 and $71 .{ }^{39}$

\footnotetext{
${ }^{36}$ Ibid., pp. 4-5.

${ }^{37}$ Central Statistical Office (KSH) [online]. [cit. 2017-04-27]. Available at: http://www.ksh.hu/docs/hun/xstadat/xstadat_eves/i_zoi007a.html.

${ }^{38}$ Ibid. [cit. 2017-04-27]. Available at: http://www.kksh.hu/docs/hun/xstadat/xstadat_eves/i_zoi007a.html.

${ }^{39}$ Ibid. [cit. 2017-04-27]. Available at: http://www.ksh.hu/docs/hun/xstadat/xstadat_eves/i_zoi007a.html.
} 


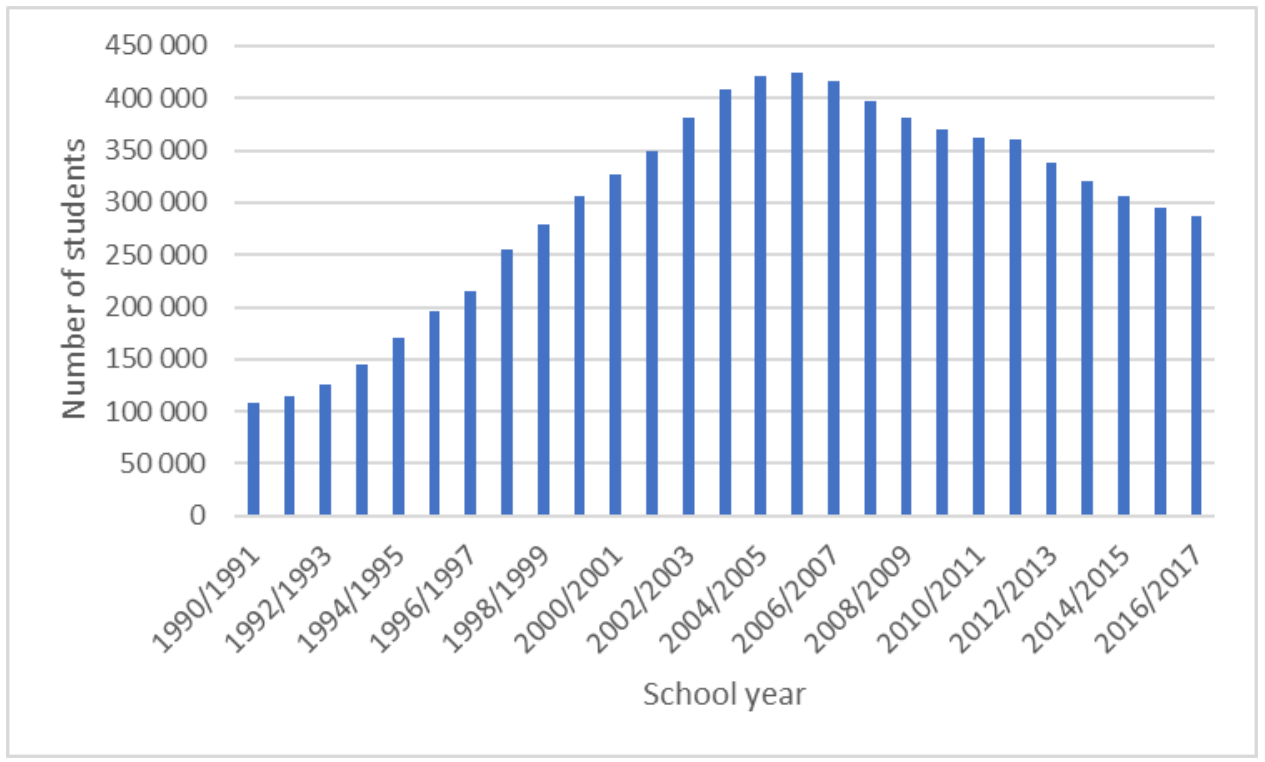

Fig. 1 The number of students in Hungarian higher education (1990-2017). Source: authors' edition (based on the data of Central Statistical Office). ${ }^{40}$

Though the paper of Fazekas and Sik (2007) helps to trace the size of the movement to 2006, it is open to question how did the number of the special colleges follow the changes of higher education. ${ }^{41}$ All this is hardly reconstructable: on one hand, the above-mentioned papers use differing definitions and methods; on the other hand, the central registration and classification of special colleges may happen in dissimilar ways. It is also a common phenomenon, that an institution describes itself as a special college, but it did not acquire legitimacy from higher education institute or educational administration.

The first accreditation procedure was called accreditation ('akkreditáció'), but the government criticised the term because of its ambiguity and suggested the ranking ('minösités') word. ${ }^{42}$ The data from $23^{\text {rd }}$ October, $2012^{43}$ possibly shows former status: the list contains 39 accredited and 34 non-accredited special colleges. The data from $8^{\text {th }}$ December, $2013^{44}$ shows a tripartite system yet: (accredited-promise-other), but, unfortunately, only the number of the accredited institutions is available (42 colleges). The situation is similar in the case of the data

\footnotetext{
${ }^{40}$ Ibid. [cit. 2017-04-27]. Available at:. http://www.ksh.hu/docs/hun/xstadat/xstadat_eves/i_zoi007a.html.

${ }^{41}$ The implementation of the Bologna reform is introduced in the following paper: Alesi, Rosznyai and Szántó (2007).

42 See the announcement in 2012 [online]. [cit. 2017-05-08]. Available at: https://webbeta.archive.org/web/20121030121600/http://www.szakkoli.hu:80/sites/default/files/palyazati_kiiras_2012.pdf. In this paper we used them as equivalent terms.

${ }^{43}$ Ibid. [cit. 2017-05-08].

Available at: https://web-beta.archive.org/web/20121023231312/http://www.szakkoli.hu:80/szakkoli-lista/nemakkreditalt.

${ }^{44}$ Ibid. [cit. 2017-05-08].

Available at: https://web-beta.archive.org/web/20131208185540/http://szakkoli.hu/szakkoli-lista. The new regulation of the tertiary education and the changing organizational features of the higher education institutions also affected these data. (cf. Kováts, 2018).
} 
from $22^{\text {nd }}$ March, 16 $6^{\text {th }}$ July, and $10^{\text {th }}$ August 2014 (45 accredited special colleges). ${ }^{45}$ According to the status of $23^{\text {rd }}$ February, 2015, only 41 accredited institutions existed in Hungary. ${ }^{46}$

The data from the end of 2015 and 2016 has been analysed earlier (cf. Garai and Szabó, 2015, 2016), but in this paper, we added the new data (2017) too (see Figure 2).

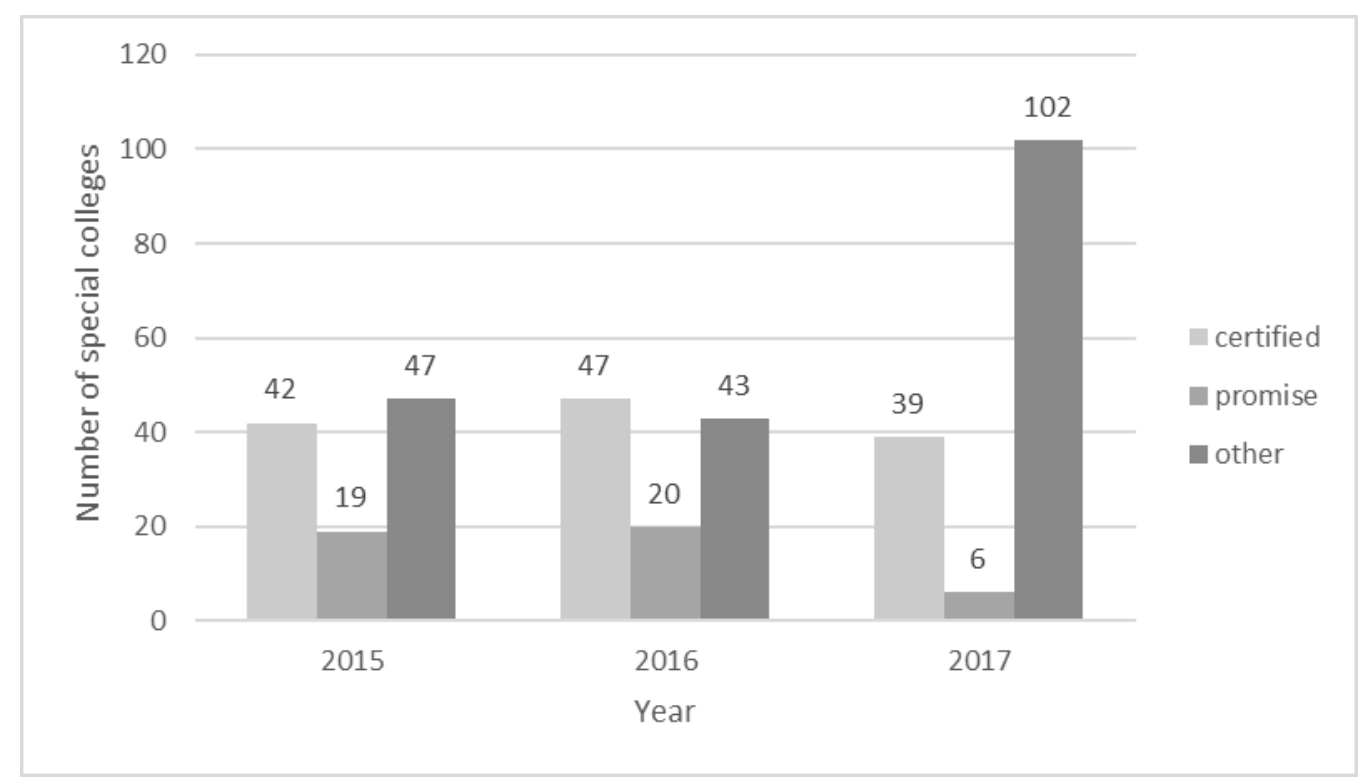

Fig. 2 The size and distribution of the special college movement. Source: authors' edition (based on SZEF's web page data).

In 2015, 108 special colleges were listed, while in 2016, their number was 110. Besides the moderate increase, it is more important to highlight the changes in the structure of the institutions' categorisation, i.e. the move from the 'other' category to the 'accredited' group. The next year showed a bigger increase, the number of the institutions increased of 37, which vast majority $(69,3 \%)$ was grouped in 'other' (more precisely, 'not certified') category. However, though a deeper statistical analysis is not possible because of the segmentation and differing typology of data, it seems that the growing trend in the special college movement continues, moreover, in 2017 explosive increase was noted. ${ }^{47}$

\footnotetext{
45 Ibid. [cit. 2017-05-08].

Available at: https://web-beta.archive.org/web/20140322021157/http://www.szakkoli.hu:80/szakkoli-lista. https://web-beta.archive.org/web/20140716032251/http://www.szakkoli.hu/szakkoli-lista. https://web-beta.archive.org/web/20140810011902/http://www.szakkoli.hu/szakkoli-lista. 46 Ibid. [cit. 2017-05-08].

Available at: https://web-beta.archive.org/web/20150223144800/http://szakkoli.hu/szakkoli-lista.

${ }^{47}$ In that year, the OECD (2017) published a short overview about the Hungarian higher education, which also summarises the key objectives of the next decade.
} 


\section{Summary}

The first precursor of the special colleges' institutional organisation were the colleges of the University of Oxford, which complemented and supported the studies of their members since the late $12^{\text {th }}$ and early $13^{\text {th }}$ century. Because of cultural interactions and peregrination, later on this form of higher education also appeared in Paris, and in the early modern age, it took particular functions of university studies both in France and in England. The development of the nation-states in the modern age also brought the establishment of their modern educational systems, which were favourably inclined towards these former institution types (colleges).

In this way, following French pattern was founded the first special college in Hungary, the Baron Eötvös József Collegium in Budapest, and later the Eötvös Loránd College in Szeged in the 1930s. Integrating French type of institutions into the institutional system of the Hungarian higher education, resulted in improving the quality of the training for two reasons. Firstly, it generated new vacant positions that could have been occupied by young and talented scholars. This enhanced the competition among institutions and increased the standards of scientific work. Secondly, the new type of institution also brought new methodological solutions in teacher training. Small group seminar classes became prevalent in higher education after the foundation of the Eötvös Collegium. These type of seminars spread over the regular training of the philosophy faculty in the first decade of the $20^{\text {th }}$ century.

Later, a very different concept resulted in the movement of the NÉKOSZ, which aimed at the talent support of broader social strata and also their roles in public life. This phenomenon helps to highlight the fact that special colleges played a significant role not just in training scientific elites but also support the political elite with young aspirants. Furthermore, it is also worth noticing that the Communist regime felt necessary to disband École type of special colleges in order to prevent them from training counter elites who might pose a threat against the new rule that came in to existence after the political regime change in 1948/1949. Consequently, the Communist dictatorship established its own elite training institution imported from the Soviet Union in order to keep candidates under heavy political and personal scrutiny.

In the second half of the $20^{\text {th }}$ century a lot of - still existing - special colleges were organised, which played an important and active role in the political change at the end of the ' $80 \mathrm{~s}$. Prevalence of special colleges can be explained by the fact that the Communist rule eased the tight grip on education especially after 1985. New initiatives and innovations were permitted that could have served the reform of the education without questioning the principles of the political system. The regime could have been more tolerant towards special colleges because these institutions offered advanced training for those who aspired to reach higher positions in the society than their parents. It was believed that fostering social mobility might have helped to maintain and preserve the rule of the Communist party. However, international developments resulted in toppling Communist regimes across Central and Eastern Europe. Interestingly, political change did not hinder the development and existence of these institutions. Social mobility continued to remain an important issue even after the fall of the 
iron curtain and these institutions offered promising services for those who opted for reaching higher positions via education.

During the change of the regime, the uncertainty of definitions and the resulting unstable environment predicted that one of the biggest challenges for the special colleges will be the creation of a solid notion base and legal environment. This process, despite the different attempts, e. g. the Charter, started relatively slow, and in detail, it is regulated only outside the legal sources today. These arrangements (first of all, the accreditation) are primarily related to the documents of the SZEF.

The size of higher education and trends in social changes were strong incentives, but later it did not affect the expansion of the movement so strongly. After 2011, the number of accredited special colleges was around 40, but the distribution of the whole movement changed a lot (it can be extracted reliably only between 2015 and 2017). According to the latest data we used (2017), the number of the accredited special colleges has not been changed considerably, but the number of the non-accredited special colleges increased remarkably.

The profiles and the functions of the special colleges after 1990 were heterogeneous, but they more or less followed the principles of the Charter. Though the political orientation of the special colleges decreased, the civic values (cf. Márkus, 2014, p. 61) and social responsibility remained important. Obviously, for these reasons movement of special colleges cannot be perceived as a conglomerate of unified institutions with similar training goals or methods. There have been significant differences in their aims and training concepts. From the historical overview of the development of special colleges it is also palpable that functions differed in each type of colleges. Some of them trained scholars while other aimed at providing new specialists for the political elite. Offering social mobility could be a common ground between special colleges with different origins. Aside from the training aims or methods, each of them provided their members with the chance to reach higher positions in the social hierarchy.

Several types of research deal with the question of special colleges, and we also intend to continue our examinations in this field: the exploration of the Educational Authority's relevant documents and the interviews with SZEF's members may give further details. 


\section{References}

ADITUS Tanácsadó és Szolgáltató Zrt., 2011. Szakkollégiumi helyzetkép felmérése [online]. Budapest [cit. 2017-08-06]. Available at:

http://ofi.hu/sites/default/files/attachments/ofi_szakkollegiumi_helyzetkep_felmerese.pdf. ALESI, Bettina, ROSZNYAI, Christina and SZÁNTÓ, Tibor, 2007. The Implementation of Bachelor and Master Programmes in Hungary. European Journal of Education [online]. 42(3), pp. 395-409 [cit. 2020-06-01]. Available at: https://doi.org/10.1111/j.14653435.2007.00316.x.

BRAHAM, Randolph Louis, 1970. Education in the Hungarian People's Republic. Washington, D. C: U.S. Government Printing Office.

BÎRZEA, César, 1994. Educational Policies of the Countries in Transition. Strasbourg: Council of Europe Press.

ČERYCH, Ladislav, KOUCKÝ, Jan and MATĚJU゚, Petr, 1999. School system and educational development. In: VEČERNÍK, Jiří and MATĚJÜ, Petr, eds. Ten Years of Rebuilding Capitalism. Czech Society after 1989. Prague: Academia.

DEMETER, Endre, 2012. Szakkollégiumok, a tehetség közege. Felsőoktatási Mühely [online]. 5(4), pp. 53-72 [cit. 2017-08-02]. Available at: http://www.felvi.hu/pub_bin/dload/FeMu/2012_4/Felsooktatasi_Muhely_2012_4_53-72. pdf.

DÉNESI, Tamás, 1995. Diákélet a régi Collegiumban. In: KÓSA, László, ed. Szabadon szolgál a szellem. Tanulmányok és dokumentumok a száz esztendeje alapított Eötvös József Collegium történetéböl 1895-1995. Budapest: Gift Kft, pp. 99-109.

FARKAS, Anikó, 2009. További gondolatok a határon túli “szakkollégiumi mozgalomról”. Magyar Tudomány. 170(12), pp. 1543-1545.

FAZEKAS, Mihály and SIK, Domonkos, 2007. A magyarországi szakkollégiumok: érdekérvényesités, forrásszerzés, kommunikáció. Kutatási zárójelentés. Budapest: Nemzeti Civil Alapprogram.

FAZEKAS, Mihály and SIK, Domonkos, 2008. A szakkollégiumok finanszírozási stratégiái és civil

jellege közötti összefüggések. Civil Szemle. 5(3), pp. 8-21.

FIZEL, Natasa, 2015. Hugarian Higher Education Policy in the Interwar Period. Délvidéki Szemle [online]. II(2), pp. 32-44. [cit. 2020-05-21]. Available at: http://www.delvidekkutato.hu/download/newspaper/2015_02_delvideki_szemle.pdf.

FELEDY, Botond, KOVÁCS, Enikő, MAYER, Evelyn, PINTÉR, Melinda, PÓLYA, Viktor, SIPKA, Bence, TÓTH, Tamás, and TAMÁS, Réka, 2014. Szakkollégiumok a nemzetközi elitoktatás tükrében. Magyar Tudomány. 175(2), pp. 228-239.

FODOR, András, 1991. A kollégium. Napló, 1947-1950. Budapest: Magvető Kiadó.

FORRAY, R., Katalin, 2016. Tehetséggondozás a felsőoktatásban. Educatio. 25(3), pp. 311317.

FORRAY, R., Katalin and BOROS, Julianna, 2009. A cigány, roma tehetséggondozás intézményei. Educatio. 18(2), pp. 192-203. 
GARAI, Imre, 2016. A magyar felsőoktatás strukturális átalakítási és államosítási kísérletei az 1949-1953 közötti időszakban. In: NÉMETH, András, GARAI, Imre and SZABÓ, Zoltán András, eds. Neveléstudomány és pedagógiai kommunikáció a szocializmus idöszakában. Budapest: Gondolat Kiadó, pp. 119-160.

GARAI, Imre, 2011. A magyar középiskolai tanári szakma kialakulása. In: HORVÁTH, László, LACZKÓ, Krisztina and TÓTH, Károly, eds. Lustrum. Ménesi út 11-13. Sollemnia aedificii a D.MCMXI inaugurati. Budapest: Typotex and Eötvös József Collegium, pp. 176202.

GARAI, Imre, 2016. A tanári elitképzés mühelye. A Báró Eötvös József Collegium története 1895-1950. Budapest: ELTE Eötvös József Collegium.

GARAI, Imre, 2019. An Elite Teacher Training Institute. The History of Eötvös József Collegium 1895-1950. Budapest: ELTE Eötvös College.

GARAI, Imre and SZABÓ, Zoltán András, 2015. A szakkollégiumi mozgalom története és jelenori kihívásai Magyarországon (1895-2015). Educatio. 24(4), pp. 118-124.

GARAI, Imre and SZABÓ, Zoltán András, 2017. A szakkollégiumi mozgalom története és jelenkori kihívásai. In: ZSOLNAI, Anikó and KASIK, László, eds. Új kutatások a neveléstudományokban 2016 - A tanulás és nevelés interdiszciplináris megközelitése. Szeged: Szegedi Tudományegyetem BTK Neveléstudományi Intézet, pp. 344-364.

HONEY, John, 1987. The Sinews of Society: the Public Schools as 'a System'. In: MÜLLER, Detlef K., RINGER, Fritz and BRIAN, Simon, eds. The Rise of the Modern Educational System: Structural Change and Social Reproduction 1870-1920. Cambridge, London and Sydney: Cambridge University Press, pp. 151-162.

LADÁNYI, Andor, 2008. A középiskolai tanárképzés története. Budapest: Új Mandátum Kiadó.

LADÁNYI, Andor, 1999. A magyar felsőoktatás a 20. században. Budapest: Akadémiai Kiadó.

KALMÁR, Melinda, 1998. Ennivaló és hozomány. A kora kádárizmus ideológiája. Budapest: Magvető Kiadó.

KARÁDY, Viktor, 2005. A francia egyetem Napóleontól Vichyig. Budapest: Felsőoktatási Kutatóintézet and Új Mandátum Kiadó.

KARSTEN, Sjoerd and MAJOOR, Dominique eds., 1994. Education in East Central Europe. Educational Changes after the Fall of Communism. Münster - New York, NY: Waxmann.

KOVÁTS, Gergely, 2018. The Change of Organizational Structure of Higher Education Institutions in Hungary: A Contingency Theory Analysis. International Review of Social Research. 8(1), pp. 74-86.

MÁRKUS, Zsuzsanna, 2014. Mi a szakkollégium? Kik a szakkollégisták? In: FÉNYES, Hajnalka and SZABÓ, Ildikó, eds. Campus-lét a Debreceni Egyetemen. Ifjúságszociológiai tanulmányok. Debrecen: Debreceni Egyetemi Kiadó.

MIKONYA, György, 2014. Az európai egyetemek története, 1230-1700. Budapest: ELTE Eötvös Kiadó. 
MÜLLER, Detlef K., 1987. The Process of Systematization: the Case of German Secondary Education. In: MÜLLER, Detlef K., RINGER, Fritz and BRIAN, Simon, eds. The Rise of the Modern Educational System: Structural Change and Social Reproduction 1870-1920. Cambridge, London and Sydney: Cambridge University Press, pp. 15-52.

NAGY, Péter Tibor, 2006. The Social and Political History of Hungarian Education [online]. Budapest: Education and Society PhD School - University of Pécs - John Wesley College [cit. 2017-08-12]. Available at: https://mek.oszk.hu/03700/03797/03797.pdf.

NÉMETH, András, 2005a. A magyar pedagógia tudománytörténete. Nemzetközi tudományfejlódési és recepciós hatások, nemzeti sajátosságok. Budapest: Gondolat Kiadó.

NÉMETH, András, 2005b. A magyar pedagógus professzió kialakulásának előtörténete. A 18. században és a 19. század első felében. Pedagógusképzés. 32(1), pp. 17-32.

NÉMETH, András and BIRÓ, Zsuzsanna Hanna, 2016. A magyar neveléstudomány diszciplína jellemzőinek és kognitív tartalmainak változásai a 20. század második felében. In: NÉMETH, András, GARAI, Imre and SZABÓ, Zoltán András, eds. Neveléstudomány és pedagógiai kommunikáció a szocializmus idöszakában. Budapest: Gondolat Kiadó, pp. 7118.

PATAKI, Ferenc, 2005. A Nékosz-legenda. Budapest: Osiris Kiadó.

PAPP, István, 2005. A Györffy István Kollégiumba felvételizők társadalmi háttere, 19401943. Múltunk. 50(1), pp. 118-146.

PUKÁNSZKY, Béla, 2004. Az iskola története a kezdetektől a 17. századig. In: NÉMETH, András and PUKÁNSZKY, Béla, eds. A pedagógia problématörténete. Budapest: Gondolat Kiadó, pp. 401-426.

PUKÁNSZKY, Béla, 2012-2013. A tanárképző intézet szerepének alakulása a magyarországi tanárképzés törétnetében. Pedagógusképzés. 10-11(39-40), pp. 73-91.

PÜNKÖSTI, Árpád, 2013. Szeplötelen fogantatás. Történelmi szociográfia [Electronic version]. Budapest: Fapadoskönyv.hu Kiadó [cit. 2017-08-06]. Available at:

https://books.google.hu/books?id=BQljAgAAQBAJ\&printsec $=$ frontcover \&hl=hu\&source=gb s_ge_summary_r\&cad $=0 \# \mathrm{v}=$ onepage $\& \mathrm{q} \& \mathrm{f}=$ false.

RADÓ, P., 2001. Transition in Education. Policy Making and the Key Educational Policy Areas in the Central-European and Baltic Countries. Budapest: Open Society Institute.

RINGER, Fritz, 1987. On Segmentation in Modern European Educational Systems: the Case of French Secondary Education, 1865-1920. In: MÜLLER, Detlef K., RINGER, Fritz and BRIAN, Simon, eds. The Rise of the Modern Educational System: Structural Change and Social Reproduction 1870-1920. Cambridge, London and Sydney: Cambridge University Press, pp. 53-88.

SIK, Domonkos, 2007. Nyilvánosság a magyarországi szakkollégiumokban. In: REICH, Orsolya, ed. A tarkaság dicsérete 2. Az Erasmus Kollégium diákjainak tanulmányai. Budapest: Erasmus Kollégium Egyesület.

SIKLÓSNÉ KOSZTRICZ, Anna, 2016. Ösztöndijasok a Szovjetunióban, 1945-1960. Thesis (PhD). Eötvös Loránd University. 
SZABÓ, Miklós, 1942. Köd az iskola körül. Híd. 3(31), pp. 7-11. Accessible: MDAL $89^{\text {th }}$ box $189^{\text {th }} /$ a. dossier.

SZABÓ, Zoltán András, 2016. A jogalkotói szándék egy lehetséges feltérképezési útja a tudományos minősítési szabályozási rendszerben - az előterjesztői indoklások köre (19491989). In: NÉMETH, András, GARAI, Imre and SZABÓ, Zoltán András, eds. Neveléstudomány és pedagógiai kommunikáció a szocializmus időszakában. Budapest: Gondolat Kiadó, pp. 203-234.

SZÖGI, László, 2008. Die Universitäten in Ungarn. Gründungswellen vom späten Mittelalter bis ins 20. Jahrhundert. In: WÖRSTER, Peter, ed. Universitäten im östlichen Mitteleuropa. Oldenbourg: De Gruyter, pp. 235-268.

WOLFENSBERGER, Marca V. C., 2015. Talent Development in European Higher Education. Honors Programs in the Benelux, Nordic and German-Speaking Countries. Cham, Heidelberg, New York, Dordrecht and London: Springer.

\section{Archival sources}

Documents of direction and education affairs of Eötvös Collegium, 1895-1945. 50 ${ }^{\text {th }}$ box, $95^{\text {th }}$ $/ 1^{\text {st }}-4^{\text {th }}$ dossier. Mednyánszki Dénes Library and Archiver (MDAL), Budapest.

Documents of physical exercises of students of Eötvös Collegium, 1895-1949. $51^{\text {st }}$ box, $98^{\text {th }}$ $/ \mathrm{a} / 1^{\text {st }}-3^{\text {rd }}$ dossier. MDAL, Budapest.

Materials of French language lectors of Eötvös, $1895-1945.46^{\text {th }}$ box, $84^{\text {th }} / \mathrm{a} / 1^{\text {st }}-7^{\text {th }}$ dossier. MDAL, Budapest.

Personal materials of headmaster Géza Bartoniek. $38^{\text {th }}$ box, $63^{\text {rd }}$ dossier. MDAL, Budapest.

Published articles in newspapers and journals about Az Eötvös Collegium. $89^{\text {th }}$ box, $189^{\text {th }}$ /a. dossier. MDAL, Budapest.

Records of sessions of teaching staff of Eötvös Collegium, 1897-1950. 54 ${ }^{\text {th }}$ box, $102^{\text {nd }} / \mathrm{a}-$ d. dossier. MDAL, Budapest.

Regulation of the Baron Eötvös József Collegium. Inner order of seminars and the library. 1895. $50^{\text {th }}$ box, $95^{\text {th }} /$ a. dossier. MDAL, Budapest.

Reports about payment of honorary teacher of Eötvös Collegium. $41^{\text {st }}$ box, $73^{\text {rd }} / 4^{\text {th }}$ dossier. MDAL, Budapest.

Secretary of Hungarian Workers Party. Session of $25^{\text {th }}$ April, 1951. 276 $6^{\text {th }}$ fond, $54^{\text {th }}$ bunch, $140^{\text {th }}$ unit. Hungarian National Archive (HNA), Budapest.

Secretary of Hungarian Workers Party. Session of $13^{\text {th }}$ February, 1952. $276^{\text {th }}$ fond, $54^{\text {th }}$ bunch, $180^{\text {th }}$ unit. HNA, Budapest.

Secretary of Hungarian Workers Party. Session of $4^{\text {th }}$ February, 1953. $276^{\text {th }}$ fond, $54^{\text {th }}$ bunch, $229^{\text {th }}$ unit. HNA, Budapest.

Political Committee of Hungarian Workers Party. Session of $29^{\text {th }}$ July, 1953. $276^{\text {th }}$ fond, $53^{\text {rd }}$ bunch, $128^{\text {th }}$ unit. HNA, Budapest. 


\section{Other types of sources}

Central Statistical Office (Központi Statisztikai Hivatal) [online]. [cit. 2017-08-06]. Available at: www.ksh.hu.

Conciliatory Forum of Special Colleges (Szakkollégiumok Egyeztető Fóruma) [online]. [cit. 2017-08-06]. Available at: www.szakkoli.hu.

Educational Authority [online]. [cit. 2015-10-12]. Available at: http://www.oktatas.hu/felsooktatas/hatosagi_ugyintezes/szakkollegiumok_nyilvantartasba_vet el. 